\title{
Removal of the toxic dinoflagellate Alexandrium tamarense (Dinophyta, Gonyaulacales) by Mnemiopsis leidyi (Ctenophora, Lobata) in controlled experimental conditions
}

Remoción del dinoflagelado tóxico Alexandrium tamarense (Dinophyta, Gonyaulacales) por Mnemiopsis leidyi (Ctenophora, Lobata) en condiciones experimentales controladas

\section{Sergio Bolasina ${ }^{1,2}$, Hugo Benavides ${ }^{1,4}$, Nora Montoya ${ }^{1}$, José Carreto ${ }^{1,4}$, Marcelo Acha ${ }^{1,3,4}$ and Hermes Mianzan ${ }^{1,3,4}$}

\begin{abstract}
${ }^{1}$ Instituto Nacional de Investigación y Desarrollo Pesquero - INIDEP, Paseo Victoria Ocampo $\mathrm{N}^{\circ} 1$, Escollera Norte, (7602), Mar del Plata, Buenos Aires, Argentina. sbolasina @ hotmail.com

${ }^{2}$ Núcleo em Ecologia e Desenvolvimento Sócio-Ambiental de Macaé -NUPEM/UFRJ, Rua São José do Barreto 764, Macaé, Rio de Janeiro, Brasil. (Present address)

${ }^{3}$ Consejo Nacional de Investigaciones Científicas y Técnicas (CONICET), Argentina

${ }^{4}$ Universidad Nacional de Mar del Plata, Funes 3350 (7600) Mar del Plata, Buenos Aires, Argentina

Abstract.- The objective of the present study is to estimate the removal capability of the ctenophore Mnemiopsis leidyi (Ctenophora, Lobata) on cultures of the toxic dinoflagellate Alexandrium tamarense (Dinophyta, Gonyaulacales). For this purpose, observations on its clearance and survival rates were made in controlled experiments, using different $A$. tamarense cell concentrations. Mnemiopsis leidyi is able to remove dinoflagellates actively from the water column only at the lowest density tested $\left(150\right.$ cells $\mathrm{mL}^{-1}$ ). Animals exposed to $300 \mathrm{cells} \mathrm{mL}^{-1}$ presented negative clearance and removal rates (survival= $67 \%$ ). All ctenophores exposed at the highest concentrations of toxic dinoflagellates (600 cells mL ${ }^{-1}$ ) died after $4 \mathrm{~h}$. Removal may occur mainly by incorporating and entangling cells in the mucus strands formed by the ctenophore, and in a lesser way by ingestion. Results indicate that higher concentrations of $A$. tamarense are fatally toxic to $M$. leidyi and that this ctenophore could control only the initial development of this dinoflagellate bloom.
\end{abstract}

Key words: Removal capability, Mnemiopsis leidyi, Alexandrium tamarense

\section{INTRODUCTION}

Dinoflagellates of the genus Alexandrium (Dinophyta, Gonyaulacales) are the most numerous and widespread saxitoxin producers, being responsible for paralytic shellfish poisoning (PSP) blooms (Taylor et al. 1995) in regions including the Argentine Sea (Carreto et al. 1998). The majority of toxic blooms have been caused by Alexandrium tamarense species complex (Cembella 1998). Maximum PSP toxicity and cell densities of the toxic dinoflagellate A. tamarense found in the Argentine shelf were associated with stratified waters of frontal zones (Carreto et al. 1986, Carreto et al. 1998). Health hazards to human and fisheries caused by toxin build-up in the food chain originated by Harmful Algal Blooms (HAB) have also been documented for our region (Carreto et al. 1986, Montoya et al. 1996).

The ctenophore, Mnemiopsis leidyi Agassiz, 1865 (Ctenophora, Lobata), is a native species from the Atlantic coasts of North and South America between $40^{\circ} \mathrm{N}$ to $46^{\circ} \mathrm{S}$
(Mianzan 1999); it is frequent and abundant in estuaries and semi-enclosed areas (Costello \& Mianzan 2003). M. leidyi has been recognized as an invasive species, altering plankton communities and impacting fisheries negatively (Costello et al. 2012). In the last 2 decades, this species successfully invaded the Black, Azov, Caspian, eastern Mediterranean, Aegean, Baltic and North seas (Shiganova $\&$ Malej 2009). The species can dominate seasonally the macro-plankton biomass of estuarine and tidal fronts, inhabiting mainly stratified waters (Mianzan et al. 2010).

Both ctenophores and dinoflagellates coexist in the same region (frontal zones) and season, so it is hypothesized that the filtering and entangling capabilities of the ctenophores and/or the toxic nature of this dinoflagellate may interact in some way. It is widely accepted that Mnemiopsis is carnivorous (Deason \& Smayda 1982), nonetheless some authors have also reported that larvae and post-larvae can consume 
significant quantities of micro-phytoplankton (Sullivan \& Gifford 2004). McNamara et al. (2013) suggested that M. leidyi blooms are the result of a direct feedback system, wherein intense feeding activity by adults on mesozooplankton releases certain microplanktonic taxa from predation pressure, thus enhancing prey conditions for larval ctenophores. Even though adult Mnemiopsis are incapable of effective herbivory to meet their energetic requirements, this ctenophore populations can in fact remove substantial quantities of vegetal cells from the water column. Moreover, Deason \& Smayda (1982) found that the chain-forming diatom Skeletonema costatum could be entangled by mucus strands and balls produced by ctenophores.

The present study attempts to estimate the capabilities of Mnemiopsis leidyi lobate stage individuals on the removal of toxic dinoflagellate Alexandrium tamarense cells. For this purpose, observations on its clearance, removal and survival rates, as well as the determination of PSP toxin content, both in the ctenophore tissue and in the dinoflagellates culture, were registered under controlled experimental conditions.

\section{MATERIALS AND METHODS}

Mnemiopsis leidyi individuals were collected from Mar del Plata harbor ( $\left.38^{\circ} 02^{\prime} \mathrm{S}, 57^{\circ} 31^{\prime} \mathrm{W}\right)$, Argentina, by gently towing a $40 \mathrm{~cm}$ diameter, $50 \mu \mathrm{m}$ mesh ring net by hand just below the water surface for several minutes. After capture, the ctenophores were maintained at in situ temperature $\left(18^{\circ}-20^{\circ} \mathrm{C}\right)$ in a planktonkreisel.

During a maintenance period of no more than 4 days, ctenophores were fed with natural concentrations of mesozooplankton obtained from the same site of collection and Artemia nauplii. Post-larval-adult stage (15$26 \mathrm{~mm}$ length) ctenophores in a good condition, with completely developed auricles and oral lobes, intact ctene rows and feeding structures were selected for the experiments (Sullivan \& Gifford 2007).

Alexandrium tamarense (Lebour) Balech toxic clone PV1005 (toxicity value $45.53 \mathrm{fmol} \mathrm{cell}^{-1}$ ) isolated from Peninsula de Valdes coast (Argentina) was used in this study. Cultures were maintained at $18^{\circ} \mathrm{C}$ in $\mathrm{L} 1$ medium (Guillard \& Hargraves 1993). Mar del Plata coastal water (0.2 ìm filtered) was used as the medium base. Before the experiments, cultures were allowed to adapt to experimental conditions for several weeks at an irradiance of $200 \mu \mathrm{E} \mathrm{m}^{-2} \mathrm{~s}^{-1}$ photosynthetically active radiation (PAR), provided by an halogen lamp on a 14:10 h light:dark cycle.
Scalar irradiance (PAR) was measured inside the flasks by means of a QSL-100 quantum sensor (Biospherical Instruments). Cultures were used at exponential growth phase.

The experimental design followed Gifford (1993). Each experiment consisted of:

- An initial and a final control treatments containing $A$. tamarense culture in $1 \mathrm{~L}$ beakers.

- An experimental treatment with 3 different dinoflagellate concentrations, all replicated 3 times. Each experimental treatment contained the microalgal culture and three $M$. leidyi individuals. Microalgal cultures were mixed gently, siphoned into $1 \mathrm{~L}$ beakers, and ctenophores were added to the experimental treatment beakers.

Water was mixed constantly by a vibrating device under the beakers and placed inside an incubator at $18^{\circ} \mathrm{C}$ in all the treatments. The duration of the experiments was $24 \mathrm{~h}$. In order to obtain proper estimations of the clearance rates, the recipient size were calculated according to Stoecker et al. (1987), considering the ratio of larval ctenophore biovolume to sea water $\leq 1: 99$.

In a previous trial (data not presented) using red tide concentration of A. tamarense of 2100 cell $\mathrm{mL}^{-1}$, ctenophores died after one hour. Because of this, 3 lower concentrations of the dinoflagellate $(150,300$ and 600 cells $\mathrm{mL}^{-1}$ ) were tested, in order to determine if filtering and entangling may occur.

In order to confirm if the ctenophore mortality on the previous experiments was due to toxins or allelopathic substances, or if it was originated by a mechanical abrasive effect on the ctenophore surface because of the high cell concentration, another trial using high concentrations (9000 cells $\mathrm{mL}^{-1}$ ) of a non-toxic microalgae (Tetraselmis maculata) was performed simultaneously.

Ctenophores length was measured with a caliper across the oral-aboral axis not including lobes $(n=36$; average length $=18.16 \mathrm{~mm}$; range $=12.86-24.1 \mathrm{~mm})$.

Cell concentrations were determined at the beginning and at the end of the experiments using a Coulter Counter TAII, with a $140 \mu \mathrm{m}$ orifice tube. The estimation for each sample concentration consisted in the average value of 5 counts.

Per capita clearance and removal rates were calculated according to Marin et al. (1986). The term ingestion rate was substituted by removal rate because it was assumed that the possible decreases in dinoflagellate concentration 
could not be necessarily due to an effective ingestion. Among-group differences in the mean value of per capita clearance and removal rates were examined by Student's $t$-test and survival rates using Chi square $\left(\chi^{2}\right)$ test using STATISCA software program.

In order to check if the toxic cells were ingested and assimilated, another experiment with ctenophores exposed at an initial concentration of 300 cell $\mathrm{mL}^{-1}$ during $48 \mathrm{~h}$ was carried out. Whole body and dissected stomodeum were processed looking for PSP toxins. The same analysis was performed on the Alexandrium tamarense cultures used in the experiment.

Toxin removal from all the samples was performed with $0.5 \mathrm{~N}$ acetic acid to prevent interconversion. Impurities were removed from the extract by passing it through Seppack columns C18 chromatography, followed by ultrafiltration with sieve $10 \mathrm{KD}$ (10000 Dalton Ultrafree-MC). After purification stages, the sample was concentrated by vacuum centrifugation to detect trace levels of toxins. The extracts obtained were analyzed by HPLC with postcolumn derivatization and fluorescence detection following the method of Oshima (1995).

\section{RESULTS AND DISCUSSION}

In control groups, Alexandrium tamarense and Tetraselmis maculata populations increased throughout the experiments. Clearance and removal rates were significantly different $(P<0.05)$ between all groups, higher values were found in the treatment with Tetraselmis maculata (Table 1). Individuals exposed to high concentrations of $T$. maculata showed no mortality. Green mucus strands were conspicuously found at the bottom of beakers, and partially digested cells were found in it.

All ctenophores exposed to the highest concentrations of toxic dinoflagellates ( 600 cells $\left.\mathrm{mL}^{-1}\right)$ died after $4 \mathrm{~h}$. At this time, ctenes stopped moving, and ctenophores sank to the bottom. In the next two hours, the body was completely disintegrated. A decrease on the phytoplankton concentrations was found in these treatments, most probably due to cells that were stuck at the surface of the ctenophore disintegrated body as confirmed by microscope observations.

Animals exposed to 300 microalgal cells $\mathrm{mL}^{-1}$ presented negative clearance and removal rates. Survival at the end of the experiment was $67 \%$. Dead organisms remained at the bottom, but nobody disintegration occurred.

Table 1. Initial cell concentration $\left(C_{0}\right)$, cell growth coefficient $(k)$, clearance rate $(F)$, removal rate $(R)$ and survival rate during the experiments. Values (mean \pm SD) with different superscripts are significantly different $(P<0.05) /$ Concentración inicial de células $\left(C_{0}\right)$, coeficiente de crecimiento celular $(k)$, tasa de depuración (clearence, $F$ ), tasa de remoción $(R)$ y tasa de supervivencia durante los experimentos. Los valores (media \pm desviación estándar) con exponentes distintos son significativamente diferentes $(P<0,05)$

\begin{tabular}{|c|c|c|c|c|c|}
\hline Treatment & $\begin{array}{c}\mathrm{C}_{0} \\
\text { (cell } \mathrm{mL}^{-1} \text { ) }\end{array}$ & $\begin{array}{c}\mathrm{k} \\
\left(\mathrm{day}^{-1}\right)\end{array}$ & $\begin{array}{c}\mathrm{F}(\mathrm{mL} \\
\left.\text { ctenophore }^{-1} \mathrm{~h}^{-1}\right)\end{array}$ & $\begin{array}{c}\mathrm{R}(\text { cells } \\
\left.\text { ctenophore }^{-1} h^{-1}\right)\end{array}$ & $\begin{array}{l}\text { Ctenophore } \\
\text { survival (\%) }\end{array}$ \\
\hline Tetraselmis maculata & 9500 & $0.19 \pm 0.03$ & - & - & - \\
\hline $\begin{array}{l}\text { Tetraselmis maculata }+ \\
\text { ctenophores }\end{array}$ & 9500 & $-0.27 \pm 0.01$ & $6.6 \pm 0.2^{a}$ & $56194 \pm 608^{a}$ & $100^{\mathrm{a}}$ \\
\hline Alexandrium tamarense & $\begin{array}{l}600 \\
300 \\
150\end{array}$ & $\begin{array}{l}0.25 \pm 0.06 \\
0.20 \pm 0.04 \\
0.32 \pm 0.06\end{array}$ & $\begin{array}{l}- \\
- \\
-\end{array}$ & $\begin{array}{l}- \\
- \\
-\end{array}$ & $\begin{array}{l}- \\
- \\
-\end{array}$ \\
\hline $\begin{array}{l}\text { Alexandrium tamarense } \\
+ \text { ctenophores }\end{array}$ & $\begin{array}{l}600 \\
300 \\
150\end{array}$ & $\begin{aligned}-0.07 & \pm 0.01 \\
0.381 & \pm 0.10 \\
-0.176 & \pm 0.004\end{aligned}$ & $\begin{array}{c}- \\
-2.5 \pm 1.5^{b} \\
5.22 \pm 0.06^{c}\end{array}$ & $\begin{array}{c}- \\
-691 \pm 305^{b} \\
899 \pm 71^{c}\end{array}$ & $\begin{array}{c}0^{\mathrm{b}} \\
67^{\mathrm{c}} \\
100^{\mathrm{a}}\end{array}$ \\
\hline
\end{tabular}


Mnemiopsis leidyi was able to actively remove dinoflagellates from the water column only at the lowest microalgal density tested (150 cells $\left.\mathrm{mL}^{-1}\right)$. In this case, individuals showed a $100 \%$ survival, displaying normal feeding behavior and producing strands with mucus throughout the duration of the experiment. Average per capita clearance rates obtained by Sullivan \& Gifford (2004) working with $15 \mathrm{~mm}$ post larval Mnemiopsis leidyi with different assemblages of microphytoplankton and microzooplankton prey was $95 \mathrm{~mL}$ individual ${ }^{-1} \mathrm{~h}^{-1}$. They found significant selection against a potentially toxic dinoflagellate, Dinophysis acuminata. In this study clearance values were lower, probably because the experiments were done with one prey item only. Moreover, the reduced feeding rate in treatments including dinoflagellates could be caused by chemosensory detection or a progressive physical incapacitation.

No evidence of digested cells was found under microscope observation. The removal may occur mainly by incorporating and entangling cells in the mucus strands formed by the ctenophore and in a lesser way by ingestion.
It is possible that dinoflagellates were partially incorporated into mucus outside the ctenophore buccal orifice. Some cells may have entered into the pharynx but possibly they were expelled in a mucus ball with others remains. This behavior has been reported for Mnemiopsis feeding on chain-forming diatoms (Deason \& Smayda 1982).

The presence of zooplankton is thought to stimulate mucus strand formation, however it was also reported that mucus can be produced in the absence of zooplankton if the density of cells is high (Deason \& Smayda 1982). In the present experiment, mucus strands were produced only at the lower dinoflagellate concentration.

PSP toxins analysis on ctenophores tissues was negative (Fig. 1), in spite of the presence of $A$. tamarense PV1005 toxic strain (toxicity value $=45.53 \mathrm{fmol} \mathrm{cell}^{-1}$ ). High contents of the potent carbamate derivative GTX4 (41 mol \%) were found, followed by considerable amounts of the sulfocarbamoyl derivatives (CTX) and gonyautoxins GTX2, and lesser levels of neoSTX and GTX1.

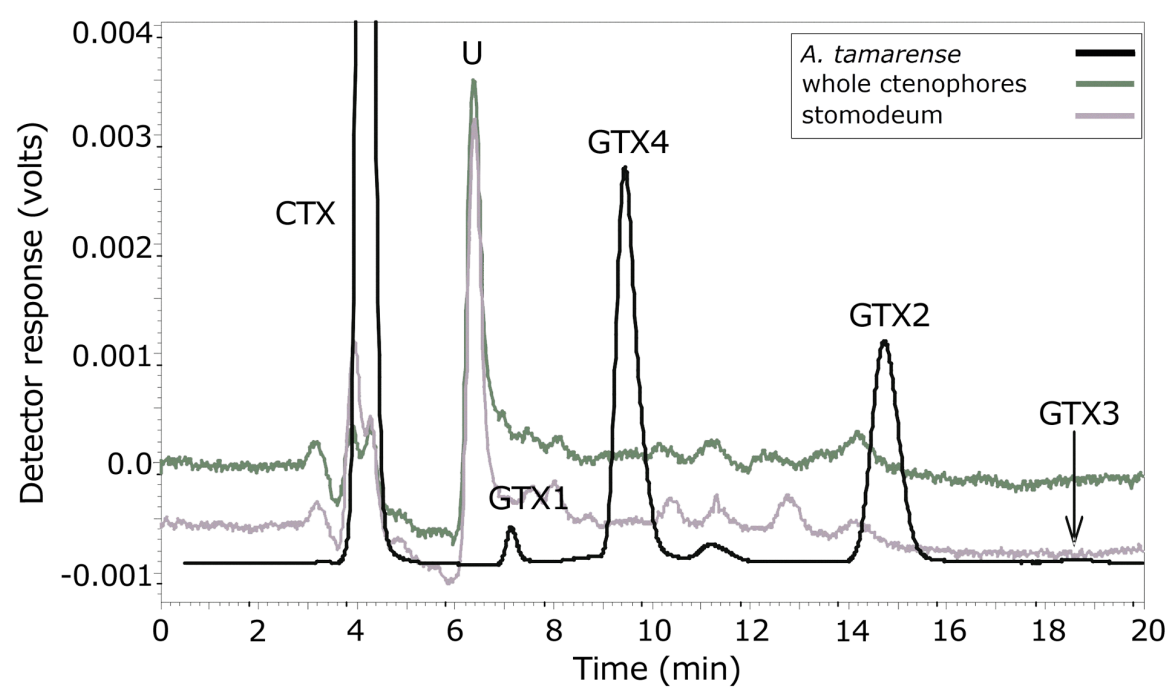

Figure 1. Chromatogram of the samples of Alexandrium tamarense, whole ctenophores and ctenophores stomodeum. GTX 1, 2, 3 and 4 corresponded to paralytic shellfish toxins Gonyautoxin 1, 2, 3, and 4 respectively; CTX: $\mathbf{N}$-sulfocarbamoyl derivatives $\mathrm{C} 1,2$ toxins; $\mathrm{U}$ unknown / Cromatograma de las muestras de Alexandrium tamarense, ctenóforos completos y estomodeo de los ctenóforos. GTX 1, 2, 3 y 4 corresponde a toxinas paralizantes de moluscos bivalvos, Gonyautoxina 1, 2, 3, y 4 respectivamente; CTX: derivados de toxinas C1,2 Nsulfocarbamoil; $U$ desconocido 
Toxins produced by dinoflagellates such as PST or other still unknown toxic substances might have been present in the culture media, probably inhibiting Mnemiopsis feeding movements and finally killing them. For example, Alexandrium leei produces a heat-stable polar ichthyotoxin, which can be released from the algal cells into the culture medium (Tang et al. 2007). PSTindependent allelopathic compounds described for Alexandrium spp. are known to cause immobilization, cellular deformation and lysis of co-occurring target organisms (Ford et al. 2008). On Figure 2 the relation between the concentration of toxic dinoflagellates and ctenophores mortality after $24 \mathrm{~h}$ is presented. This curve displays the general form of a dose response curve: low mortality at low concentrations of the toxicant increasing to high mortality at higher doses.

Mnemiopsis was proposed as an important source of macroscopic mucus aggregates, increasing the "package size' of the phytoplankton, thus influencing its sinking rates (Deason \& Smayda 1982). If this experimental observation regarding mucus development represented what actually happens in natural conditions, the formation of larger mucous particles containing undigested $A$. tamarense cells may restrict PST transference to higher trophic levels.

Removal by ctenophores can be of significance in controlling a possible bloom in nature if the concentration of the ctenophore is sufficiently high and the concentration of Alexandrium tamarense is low (e.g., at the beginning of a seasonal peak in abundance), In contrast, elevated concentrations of the dinoflagellate can cause a high mortality in the adult ctenophore population. Future investigations must focus on the evaluation of predatory impact during earlier larval stages, in conjunction with toxicity levels determination in the presence of dissolved toxic substances.

\section{ACKNOWLEDGments}

This work was partially supported by the following grants: 'Agencia Nacional de Promoción Científica y Tecnológica' PICT 1553, Universidad Nacional de Mar del Plata EXA 470/10 and the Inter-American Institute for Global Change Research (IAI) CRN 4202076 sponsored by the US National Science Foundation Grant GEO-0452325 to HM \& MA.

In memoriam of Hermes Walter Mianzán (1957-2014).

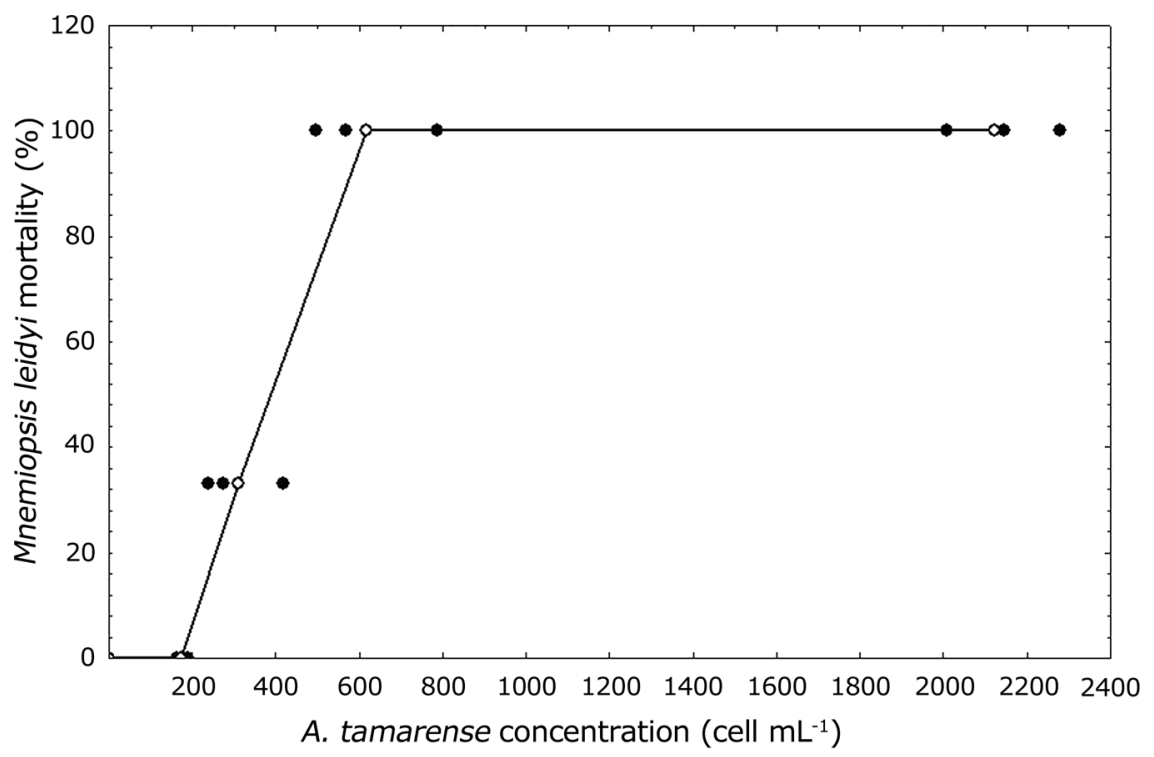

Figure 2. Toxicity curve obtained from the experiments with Mnemiopsis leidyi with different concentrations of the toxic dinoflagellate Alexandrium tamarense / Curva de toxicidad obtenida de los experimentos con Mnemiopsis leidyi y diferentes concentraciones del dinoflagelado tóxico Alexandrium tamarense 


\section{LITERATURE CITED}

Carreto JI, HR Benavides, RM Negri \& PD Glorioso. 1986. Toxic red-tide in the Argentine Sea. Phytoplankton distribution and survival of the toxic dinoflagellate Gonyaulax excavata in a frontal area. Journal of Plankton Research 8: 15-28.

Carreto JI, R Akselman, NG Montoya, RM Negri, HR Benavides, MO Carignan \& D Cucchi-Colleoni. 1998. Alexandrium tamarense blooms and shellfish toxicity in the Argentine Sea: a retrospective view. In: Reguera B, J Blanco, ML Fernández \& T Wyatt (eds). Harmful microalgae, pp. 131-134. Xunta de Galicia, IOC-UNESCO, Santiago de Compostela.

Cembella AD. 1998. Ecophysiology and metabolism of paralytic shellfish toxins in marine microalgae. In: Anderson DM, AD Cembella \& GM Hallegraeff (eds). Physiological ecology of Harmful Algal Blooms, pp. 381-403. NATO ASI Series. Springer, Berlin.

Costello JH \& HW Mianzan. 2003. Sampling field distributions of Mnemiopsis leidyi Ctenophora, Lobata): planktonic or benthic methods? Journal of Plankton Research 25: 455-459.

Costello JH, KM Bayha, HW Mianzan, TA Shiganova \& JE Purcell. 2012. The ctenophore Mnemiopsis leidyi transitions from a native to an exotic species. Hydrobiologia 690: 21-46.

Deason EE \& TJ Smayda. 1982. Experimental evaluation of herbivory in the ctenophore Mnemiopsis leidyi relevant to ctenophore-zooplankton-phytoplankton interactions in Narragansett Bay, Rhode Island, USA. Journal of Plankton Research 4: 219-236.

Ford SE, VM Bricelj, C Lambert \& C Paillard. 2008. Deleterious effects of a non PST bioactive compounds from Alexandrium tamarense on bivalve hemocytes. Marine Biology 154: 241-253.

Gifford DJ. 1993. Consumption of Protozoa by copepods feeding on natural microplankton assemblages. In: Kemp PF, BF Sherr, EB Sherr \& JJ Cole (eds). Handbook of methods in aquatic microbial ecology, pp. 723-729. Lewis Publishers, Boca Raton.

Guillard RRL \& PE Hargraves. 1993. Stichochrysis inmobilis is a diatom, not a chrysophyte. Phycologia 32: 234-236.

Marin V, ME Huntley \& BW Frost. 1986. Measuring feeding rates of pelagic herbivores: analysis of experimental design and methods. Marine Biology 93: 49-58.
McNamara ME, DJ Lonsdale \& RM Cerrato. 2013. Topdown control of mesozooplankton by adult Mnemiopsis leidyi influences microplankton abundance and composition enhancing prey conditions for larval ctenophores. Estuarine, Coastal and Shelf Science 133: 2-10.

Mianzan H, P Martos, J Costello \& R Guerrero. 2010. Avoidance of hydrodynamically mixed environments by Mnemiopsis leidyi (Ctenophora: Lobata) in open-sea populations from Patagonia, Argentina. Hydrobiologia 645: 113-124.

Mianzan HW. 1999. Ctenophora. In: Boltovskoy D (ed). South Atlantic zooplankton, pp. 561-573. Backhuys Publishers, Leiden.

Montoya NG, R Akselman, J Franco \& JI Carreto. 1996. Paralytic shellfish toxins and mackerel (Scomber japonicus) mortality in the Argentine Sea. In: Yasumoto T, Y Oshima \& Y Fukuyo (eds). Harmful and toxic algal blooms, pp. 417-420. IOC, UNESCO, Paris.

Oshima Y. 1995. Postcolumn derivatization liquid chromatography method for paralytic shellfish toxins. Journal of AOAC International 78: 528-532.

Shiganova T \& A Malej. 2009. Native and non-native ctenophores in the Gulf of Trieste, Northern Adriatic Sea. Journal of Plankton Research 31: 61-71.

Stoecker DK, PG Verity \& AE Michaels. 1987. Feeding by larval and post-larval ctenophores on microzooplankton. Journal of Plankton Research 9: 667-683.

Sullivan LJ \& DJ Gifford. 2004. Diet of the larval ctenophore Mnemiopsis leidyi A. Agassiz (Ctenophora, Lobata). Journal of Plankton Research 26: 417-431.

Sullivan LJ \& DJ Gifford. 2007. Growth and feeding rates of the newly hatched larval ctenophore Mnemiopsis leidyi A. Agassiz (Ctenophora, Lobata) Journal of Plankton Research 29: 949-965.

Tang YZ, L Kong \& MJ Holmes. 2007. Dinoflagellate Alexandrium leei (Dinophyceae) from Singapore coastal waters produces a water-soluble ichthyotoxin. Marine Biology 150: 541-549.

Taylor FJR, Y Fukuyo \& J Larsen. 1995. Taxonomy of harmful dinoflagellates. In: Hallegraeff GM, DM Anderson \& AD Cembella (eds). Manual on harmful marine microalgae. IOC Manuals and Guides 33: 1-33. Intergovernmental Oceanographic Commission of UNESCO, Paris. 